\section{Crossing the water}

France and Britain now seem bent on building a physical link. Will it really happen?

THE bids announced last week by the consortia wishing to build a physical link between Britain and France have been widely predicted and are, as far as they go, staid and safe. The Channel Tunnel Company, which already owns a number of holes in the ground and beneath the seabed on the English side of the water, is understandably bent on building a tunnel, a rather better one than that abandoned in the early 1970s. Others are variously concerned to build a bridge the whole way across this turbulent 21 miles of water, or to span just over half of it with bridge-like structures that then disappear beneath the sea in a stretch of tunnel that will allow shipping to pass without hindrance. The tunnel, which would accommodate only trains, is the cheapest project (at roughly $£ 2,500$ million). The bridge-tunnel plan is roughly twice as expensive; building a bridge the whole way across (with an accompanying railway tunnel with which to placate the nationalized railway systems on each side of the Channel) works out at half as much again. The only certainty about what will happen next is that the governments of France and Britain will decide on the scheme to be allowed to go ahead, but that the construction costs will have to be met by private interests, banks and the like.

So has the time arrived when the future of the Channel tunnel link will be laid to rest? Most probably not. For the best part of two centuries, schemes to build a Channel link have been canvassed enthusiastically and, then, as suddenly abandoned. The fear that Napoleon might be able to march an army through a tunnel brought the first wave of enthusiasm to a halt. Now, not even fears of cultural invasion can upset the case for building a link of some kind across the Channel, which is crudely economic. All the bidders now in the market for the attention of their governments base their arguments on the assumption that the cross-Channel business will be worth $£ 500$ million a year or so by the time that a tunnel or a bridge is built. If the estimates of cost now put forward are anything like correct, each of the schemes should be economically viable at some point in the 1990s. But how likely are the planners to be proved correct? And what will happen if their estimates are seriously in error, and if the project chosen in the next few months runs into trouble, geological or financial, in the succeeding years?

Whatever the two governments may say, they cannot wash their hands of some kind of responsibility for whichever project they choose. From the start, they will be intimately involved, as governments, in the renegotiation of navigation rules between France and Britain. And on each side of the Channel, the project will need planning permission on a scale that only governments can provide. Then, in reality, there is no chance that either government could turn its back if a project turned sour after a few years. At the very least, it might be necessary to dismantle a few surplus structures in the centre of a busy international waterway. But the political pressures that would apply to government that decided it could abandon a physical link halfway through construction would be irresistible.

That is one reason why there is the strongest case for the two governments to face the responsibilities they will not be able to escape now, and not to wait until the project is under way, with money committed. It is right and proper that they should expect the bulk of the funds required for the project to be raised from private sources, but it would help to give the project solid foundations if the two governments were to become minority shareholders in their own right. Then, if the worst came to the worst, they would be in a position to decide whether to step in to mount a rescue for a faltering project or to continue to stand aside.

Meanwhile, it remains to be seen which project will be chosen. Given their mutual interests in the prosperity of railways, both governments have a vested interest in the rail tunnel, but this should be suppressed. The high economic value of the traffic between Britain and France, and the pace at which it is growing, shows that the trade transcends the narrow interests of the railway industries. To be able to drive across as well as go by train should be the objective, whence the case for the hybrid bridge and tunnel at the very least. The misfortune in all this, however, is that so little has been done to implement what is obviously the best of all ways of crossing the Channel, the scheme for putting the clock back to the late Pleistocene, when lots of people crossed from France to Britain, and building a dam across this narrow strip of water, nowhere more than 120 feet deep.

\section{No tin-pan alley}

The International Tin Council, an international cartel, is in trouble. The surprise is the delay.

Two weeks ago, the London Metal Exchange was thrown into chaos by the announcement that the gentleman called the buffer stock manager of the International Tin Council had run out of money. Trading in tin was promptly suspended, and has not yet been resumed. Meanwhile, commodity brokers in the City of London, used as they are to skating on thin ice, are worried sick by the prospect that some of them may not be able to pay the debts they have incurred over the past several months in buying and selling tin. Even the British government, in its avuncular role as the custodian of the last resort of the reputation of the City for honest dealing, is alarmed that the reputations of people and of insitutions may be so damaged that people elsewhere will not use London as a place in which to buy and sell metals and other commodities. (London has a virtual monopoly on metaltrading.) The several causes of the tin crisis have by now been well catalogued. Improbably, they range from the illicit activities of poachers based in Singapore who have been dredging tin from the deep waters of Malaysia to the cupidity of the tinproducing countries, which have done everything they can to keep up the retail price of tin, including the curious practice of buying back through the Tin Council roughly a third of all the metal their producers have been able to sell. Collectively, the tin producers and their customers have been united through the International Tin Agreements, by whose terms the International Tin Council exists, in an attempt to ensure that water runs uphill. In the past few days, the natural laws have reasserted themselves.

Nobody should be a whit surprised. All along, the objective of the Tin Council has been to stabilize the price of tin. The buffer stock manager has instructions to buy the metal when the price falls below a certain value (fixed periodically) and to sell when the price exceeds another value. In between, however, he is neutral, sitting on the stocks he has accumulated. Although the United States has remained stolidly outside the tin agreements, other consumers have over the years benefited almost as much as the tin producers. Prices have indeed been stable, much more than might be expected in a market in which the balance between supply and demand can fluctuate enormously. The trouble is that, as in the petroleum market, stability means different things to producers and consumers. In tin, the chief producers, among whom Malaysia is the most important, have naturally taken the view that stability is not worthwhile unless it also implies a high price, just over $£ 8,000$ a tonne when trading was halted ten days ago. But the industrial demand for tin has shrunk as the many importers of this expensive metal have learned to use others instead. In retrospect, it is clear that the buffer stock manager should have blown the whistle earlier, and that he should not have waited until he ran out of credit with the banks to whom the tin market now owes the best part of $£ 600$ million. Rarely can the buffer stock have grown as consistently as in the past few months. But the diagnosis is easier after the event. And now, when nothing is sure except that a great many people and banks will be left holding a large quantity of tin they do not want, the lesson to be learned from this discreditable episode is that the laws of supply and demand are not safely defied. 